ing, thus decreasing contact time between the aspirin solution and gastric mucosa.

Of two commercially available preparations of buffered aspirin, Bufferin contains only $3 \mathrm{mmol}(\mathrm{mEq}$ ) of bicarbonate in the amount of aspirin used in this study while Alka-Seltzer contains two and a half times the amount of buffer used-that is, about $45 \mathrm{mmol}$ bicarbonate per $728 \mathrm{mg}$ sodium salicylate. Thus Bufferin almost certainly contains too little buffer to protect against aspirin damage while Alka-Seltzer contains enough to do so. Nevertheless, Alka-Seltzer contains other ingredients and is a hyperosmotic solution $\left(\mathrm{Na}^{+}\right.$concentration $280 \mathrm{mmol} / \mathrm{l}$; osmotic pressure $590 \mathrm{mmol}(\mathrm{mOsm}) / \mathrm{kg}$ ), so its effects on gastric mucosal histology need to be tested separately. Interestingly, Alka-Seltzer raises the potential difference in man over values produced by saline. ${ }^{19}$

Although the increase in potential difference produced by sodium bicarbonate is interesting, the mechanism of the increase cannot be determined from this study. It may be related to changes in the distribution of $\mathrm{Na}^{+}, \mathrm{Cl}^{-}$, or $\mathrm{H}^{+}$ions, all of which may affect potential difference. ${ }^{20}$ Nevertheless, we can conclude that aspirin adequately buffered with sodium bicarbonate prevents both the aspirin-induced fall in potential difference and histological damage caused by aspirin.

A paper based on this work was presented at the annual meeting of the American Gastroenterological Association, Toronto, Canada, May 1977. The work was supported in part by the Medical Research Service of the Veterans Administration, grants from the American Gastroenterological Association, and the patient study facilities of the UMMC Clinical Research Center.

Requests for reprints should be addressed to: Dr Kevin J Ivey,
University of Missouri, Department of Medicine, Columbia, Missouri 65201.

\section{References}

${ }^{1}$ Baskin, W N, et al, Annals of Internal Medicine, 1976, 85, 299.

2 Davenport, H W, American Fournal of Digestive Diseases, 1976, 21, 141.

Thorsen, W B, Western, D, Tanaka, Y, et al, Archives of Internal Medicine, 1968, 121, 499.

${ }^{4}$ Wood, P H N, Harvey-Smith, E A, and Dixon, A St J, British Medical fournal, 1962, 1, 669.

5 Stubbe, L T F L, Pietersen, J H, and Van Heulen, C, British Medical fournal, 1962, 1, 675 .

${ }^{6}$ Andersson, S, and Grossman, M I, Gastroenterology, 1965, 49, 364.

' Fordtran, J S, Morawski, S G, and Richardson, C T, New England Journal of Medicine, 1973, 288, 923.

${ }^{8}$ Millonig, G, Fournal of Applied Physics, 1961, 32, 1637.

${ }^{9}$ Watson, M L, fournal of Biophysical and Biochemical Cytology, 1958, 4, 475.

${ }^{10}$ Reynolds, E S, fournal of Cell Biology, 1963, 17, 208.

${ }^{11}$ Meller, S M, et al, Anatomical Record, 1973, 176, 245.

12 Krause, W J, and Leeson, C R, American fournal of Anatomy, 1973, 137, 337.

${ }_{13}$ Rehm, W R, American fournal of Physiology, 1944, 140, 720.

${ }^{14}$ Ivey, K J, Medical Clinics of North America, 1974, 58, 1289.

${ }^{15}$ Ivey, K J, Baskin, W, and Jeffrey, G, Lancet, 1975, 2, 1072.

${ }^{16}$ Leonards, J R, and Levy, G, Fournal of Pharmaceutical Sciences, 1969, 58, 1277.

17 Davenport, H W, Gastroenterology, 1966, 50, 487.

${ }_{18}$ Roth, J L A, et al, Gastroenterology, 1963, 44, 146.

${ }^{19}$ Murray, H S, Strottman, M P, and Cooke, A R, British Medical fournal, 1974, 1, 19.

${ }^{20}$ Ivey, K J, Gastroenterology, 1971, 61, 247.

(Accepted 15 August 1977)

\title{
Survivors of ruptured abdominal aortic aneurysm: the iceberg's tip
}

\author{
ROGER H ARMOUR
}

British Medical fournal, 1977, 2, 1055-1057

\begin{abstract}
Summary
In four and a half years 25 patients in one community suffered a ruptured abdominal aortic aneurysm. Eleven died at home, nine died without operation in hospital, and only five had the aneurysm removed. There were four survivors. A further seven patients might have lived had they had a prompt operation. The average operative mortality for ruptured aneurysms among series reported in British journals is $53 \%$, but the survivors are a small minority of the total number of people in the community whose aneurysms rupture. No basis could be found for the view that replacing an aortic aneurysm with a straight graft (while leaving behind aneurysmal common iliac arteries) lowers the operative mortality. On the contrary, oversimplifying the operation may be hazardous.
\end{abstract}

Lister Hospital, Stevenage, Herts SG1 4AB

ROGER H ARMOUR, FRCS, MRCP, consultant surgeon

\section{Introduction}

In 1965 Turk $^{1}$ suggested that only a small proportion of patients with a ruptured abdominal aortic aneurysm received surgical treatment. His paper attracted little interest. Most surgeons have concentrated on trying to improve treatment, and it has recently been claimed that replacement of the aneurysm with a straight tube graft instead of the more usual bifurcation graft lowers the operative mortality."

I decided to investigate the effect of surgery on the mortality of ruptured aneurysms in the community and to examine the hypothesis that straight tube grafts are best.

\section{Patients and methods}

The records of patients who were treated for or died from a ruptured atherosclerotic abdominal aortic aneurysm in north Hertfordshire from 1 September 1972 (when the Lister Hospital opened) to 28 February 1977 were studied. The 500-bed hospital serves a population of 175000 .

The diagnosis was made at operation or necropsy (22 patients) or on clinical grounds (three patients). There was a single, fatal, example of a ruptured, dilated, atherosclerotic common iliac artery which was included in the series, but dissecting and mycotic aneurysms were not.

Operative technique-Patients who had the aneurysm resected were resuscitated with isotonic saline before operation. A midline abdominal incision was made, the posterior peritoneum was opened, and after dissecting through the retroperitoneal haematoma a vascular 
clamp was applied to the aorta above the aneurysm. On two occasions incision of the posterior peritoneum resulted in sudden torrential arterial bleeding which was controlled by manual compression of the aorta above the aneurysm against the spine until clamping could be achieved. The iliac arteries were clamped without separating them from the underlying veins and the inferior mesenteric artery was ligated at its origin but not divided. A woven Dacron bifurcation graft was sutured in place using the inlay (or intrasaccular) technique. ${ }^{3}$

\section{Results}

Twenty-five patients, only two of whom were women, had ruptured aneurysms. The operations and necropsies all showed large retroperitoneal haematomas, but in only one patient had this torn the posterior peritoneum. None of the aneurysms affected the renal arteries.

Deaths outside hospital-Eleven patients died outside hospital. Of the nine who came to necropsy, five had been found dead in bed or had died suddenly, three died a few hours after the onset of abdominal pain, and one, a railwayman, who did not seek medical advice for backache of two days' duration, was found dead alongside a railway track. Further details of the case histories were not sought in case inquiries distressed the relatives. Of the two patients in whom the aneurysm was diagnosed clinically, one was a hemiplegic known to have an abdominal aneurysm, and the other died an hour after refusing an operation when I had visited him at home. Five patients were aged over 79 years and the others were aged 56-74.

Deaths in hospital-Ten patients died in hospital. Nine died without resection of the aneurysm but three also had another serious diseasechronic renal failure, bronchogenic carcinoma, or hemiplegia with aphasia. Three patients were incorrectly diagnosed, and in three the correct diagnosis was made but the aneurysm was thought to affect the renal arteries: none were referred for resection of the aneurysm, but two died very soon after admission. The tenth death occurred seven weeks after resection of a ruptured aneurysm. At the end of the operation a transverse colostomy had to be performed because an obstructing carcinoma of the descending colon was discovered. There followed a unique but depressing opportunity to observe the progress of fatal ischaemic colitis. The mucous membrane of the colostomy gradually became jet black but several litres of greenish fluid continued to fill the colostomy bags each day until the patient died. Permission for necropsy was refused. Two patients were aged over 79 years and the others were aged 63-78.

Survivors-Four of the five patients who had the aneurysm resected lived (table 1). Bifurcation grafts were used because the aortic bifurca-

TABLE I-Details of five men who had resection of a ruptured abdominal aortic aneurysm

\begin{tabular}{|c|c|c|c|c|}
\hline $\begin{array}{l}\text { Case } \\
\text { No }\end{array}$ & Age & $\begin{array}{l}\text { Interval between } \\
\text { rupture and } \\
\text { operation }\end{array}$ & Shock ${ }^{+}$ & Result \\
\hline 1 & 78 & 1 hour* & Severe & $\begin{array}{l}\text { Died at } 7 \text { weeks from ischaemia } \\
\text { and carcinoma of colon }\end{array}$ \\
\hline $\begin{array}{l}\cdots \\
\cdots \\
\cdots\end{array}$ & $\begin{array}{l}62 \\
75 \\
56 \\
64\end{array}$ & $\begin{array}{r}17 \text { hours } \\
36 \text { hours } \\
24 \text { hours } \\
6 \text { hours }\end{array}$ & $\begin{array}{l}\text { Severe } \\
\text { Severe } \\
\text { Absent } \\
\text { Severe }\end{array}$ & $\begin{array}{l}\text { Well at } 30 \text { months } \\
\text { Well at } 24 \text { months } \\
\text { Well at } 12 \text { months } \\
\text { Well at } 6 \text { months }\end{array}$ \\
\hline
\end{tabular}

* Ruptured in hospital.

+Severe shock: patient had cold clammy skin, severe pallor, and systolic blood pressure below $80 \mathrm{~mm} \mathrm{Hg}$.

tion had to be bypassed in every case. One patient had hard, calcified plaques extending well beyond the bifurcation, two had widely separated common iliac origins from the aorta, and two had aneurysms of the common iliac arteries. One of the survivors had two brothers who also suffered ruptured abdominal aortic aneurysms, which were treated in other hospitals. ${ }^{4}$ There was no obvious hereditary cause such as Marfan's syndrome.

\section{Discussion}

In this series only one in every five patients received surgical treatment; near-equal numbers of the remainder died at home or died untreated in hospital. A few surgeons have compared the number of patients who have an aneurysm excised with the
TABLE II-Fate of patients admitted to hospital with ruptured abdominal aortic aneurysms

\begin{tabular}{|c|c|c|c|c|c|c|}
\hline \multicolumn{4}{|c|}{ References } & \multirow{2}{*}{$\begin{array}{c}\begin{array}{c}\text { Patients who } \\
\text { died without } \\
\text { operation }\end{array} \\
10 \\
5 \\
11 \\
14 \\
26 \\
9 \\
\end{array}$} & \multirow{2}{*}{$\begin{array}{c}\begin{array}{c}\text { Patients who } \\
\text { underwent } \\
\text { operation }\end{array} \\
4 \\
5 \\
17 \\
10 \\
18 \\
5\end{array}$} & \multirow{2}{*}{$\begin{array}{c}\begin{array}{c}\text { Survivors } \\
\text { after } \\
\text { operation }\end{array} \\
1 \\
2 \\
5 \\
4 \\
4 \\
4\end{array}$} \\
\hline $\begin{array}{l}\text { Mavor et al al } \\
\text { Savage et al } l^{16} \\
\text { Martin } 17 \\
\text { Calne } \\
\text { Pryor }^{6} \\
\text { Present series }\end{array}$ & $\begin{array}{l}\cdots \\
\cdots \\
\cdots \\
\cdots \\
\cdots\end{array}$ & $\begin{array}{l}\ldots \\
\cdots \\
\cdots \\
\cdots\end{array}$ & $\begin{array}{l}\ldots \\
\cdots \\
\cdots \\
\cdots\end{array}$ & & & \\
\hline Total & . & . & . & 75 & 59 & \\
\hline Grand total & .. & .. & $\ldots$ & \multicolumn{2}{|c|}{134} & $20\left(15{ }^{\prime \prime}{ }_{0}\right)$ \\
\hline
\end{tabular}

number who die in hospital without operation (table II). Talbot and Langman ${ }^{5}$ showed how hospital statistics on ruptured aneurysms considerably underestimate the community mortality. In their survey 72 patients died in hospital and 93 outside. When deaths outside hospital are taken into account the survivors of ruptured abdominal aortic aneurysm form a very small group; they may be compared to the tip of an iceberg, the submerged nine-tenths of which represents the patients who died. Treatment therefore has relatively little effect on the community mortality, but without it there would be no survivors.

Those who die at home are among the ones who might have been saved by excision of the aneurysm before it ruptured. Elective removal of an aneurysm carries a low mortality, and a patient who is otherwise well should be referred for operation as soon as possible. Many aneurisms rupture without warning, however, so that the patient does not seek advice before the catastrophe. Screening the population for symptomless aneurysms would present insurmountable problems. The only practical solution is for rupture to be recognised and treated earlier in those who survive the initial haemorrhage. In the present series three of the patients who died at home lived for a few hours after rupture, but it is not known whether they saw a doctor.

Patients living long enough to reach hospital have been favoured by the process of natural selection-those less fit having already died-yet in this survey only four out of 14 left hospital alive. Excluding the patients who died soon after admission and those who had other serious diseases, there were four patients who may have lived had they been correctly managed. Pryor ${ }^{6}$ showed how serious the problem can be: in his series only four of the 44 patients admitted to hospital survived.

Although the first successful resections of ruptured abdominal aortic aneurysms were reported in $1954,{ }^{7-9}$ Graham et al ${ }^{10}$ calculated an average operative mortality of $56 \%$ in a collected series of 756 operations. As recently as 1974 David et al ${ }^{11}$ reported losing all 14 patients on whom they operated. The published operative mortality rates in the United Kingdom are shown in table III. The high mortality shows little sign of falling

TABLE III-Results found in British journals of operations for ruptured abdominal aortic aneurysms

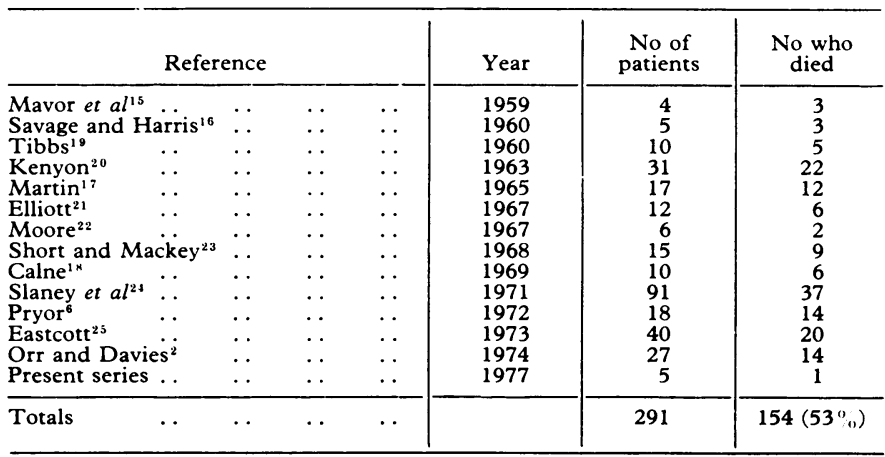


and is acceptable only because death is almost inevitable without operation.

Attempts to improve the operation and make it safer have led to several modifications. Thus, some surgeons have not removed the wall of the aneurysm and have used it to fold over the graft, which may be anastomosed by the inlay technique. Others have replaced the aneurysm by a straight tube graft when the aortic bifurcation is relatively healthy. Aortic aneurysms often splay the bifurcation, however, and are often associated with diseased or aneurysmal common iliac arteries. Orr and Davies ${ }^{2}$ suggested that aneurysmal common iliac arteries with quite widely separated origins from the aorta are not necessarily an indication for a bifurcation graft, and they used straight grafts for aortic aneurysms in $90^{\circ}{ }_{0}$ of their more recent cases. This is a higher figure than that recorded by any other surgeons. Furthermore, they attributed a reduction in operative mortality from $64^{\circ}{ }_{0}$ to $38 \%$ to a change from bifurcation to straight grafts. Much more evidence will be required before these conclusions can be accepted.

Operative mortality depends on many variables, including the patient's age, the degree of shock, the presence of other disease, and accidents during the operation. My series, although consisting of only five patients, did not include a patient who would have been suitable for a straight graft. Chiariello $e t a l^{12}$ recorded a $79^{\circ}{ }_{0}$ survival in their large series of ruptured aneurysms, but they were able to use straight grafts in only $16 \%$ of cases. Aneurysm of the common iliac artery is not a benign disease. I found one fatal ruptured common iliac artery in the hospital series and Graham et $a l^{13}$ recorded five ruptured iliac aneurysms. Barker ${ }^{14}$ warned that dilatation of the common iliac artery may progress to late rupture below a straight graft. The choice of a straight graft should therefore depend on the finding of relatively normal iliac arteries. A bifurcation graft is safer when these vessels, or their origins from the aorta, are grossly abnormal.

I thank Mrs Sally Knight and her staff of the Lister Hospital library, for help in obtaining the references, $\mathrm{Dr} \mathrm{K}$ Misch for allowing me to study the necropsy records and specimens, Mrs Joan Houle for typing the manuscript, Mr J J Shipman, for his interest, and my wife for her encouragement. I am grateful for the stimulus and inspiration of the medical writing workshop in Birmingham.

\section{References}

1 Turk, K A D, Proceedings of the Royal Society of Medicine, 1965, 58, 869. ${ }^{2}$ Orr, W M, and Davies, M, British fournal of Surgery, 1974, 61, 847.

${ }^{3}$ Creech, O, Annals of Surgery, 1966, 164, 935.

${ }^{4}$ Clifton, M A, British fournal of Surgery. In press.

5 Talbot, S, and Langman, M J S, Postgraduate Medical fournal, 1972, 48, 414.

${ }^{6}$ Pryor, J P, British Medical fournal, 1972, 3, 735.

7 Cooley, D A, and DeBakey, M E, Postgraduate Medicine, 1954, 16, 334.

${ }^{8}$ Bahnson, H T, Circulation, 1954, 9, 494.

${ }^{9}$ Gerbode, F, Surgery, Gynecology and Obstetrics, 1954, 98, 759.

${ }_{10}$ Graham, A L, et al, Archives of Surgery, 1968, 97, 1024.

${ }^{11}$ David, J P, Marks, C, and Bonneval, M, Surgery, Gynecology and Obstetrics, 1974, 138, 591 .

12 Chiariello, L, et al, American fournal of Surgery, 1974, 128, 735.

${ }^{13}$ Graham, K J, Cole, D S, and Barratt-Boyes, B G, Australian and New Zealand fournal of Surgery, 1971, 41, 113.

${ }^{14}$ Barker, W F, Peripheral Arterial Disease, 2nd edn, p 412 and 430. Philadelphia, Saunders, 1975.

${ }^{15}$ Mavor, G E, Davidson, L D, and Clark, C G, British fournal of Surgery, 1959, 47, 292.

16 Savage, C R, and Harris, J D, Lancet, 1960, 2, 466.

17 Martin, P, Proceedings of the Royal Society of Medicine, 1965, 58, 867.

18 Calne, R Y, Annals of the Royal College of Surgeons of England, 1969, 44, 18.

19 Tibbs, D J, Lancet, 1960, 2, 1313.

${ }^{20}$ Kenyon, J R, Annals of the Royal College of Surgeons of England, 1963, 32, 116.

${ }^{21}$ Elliott, J, Anasthesia, 1967, 22, 406

${ }_{22}$ Moore, H D, Lancet, 1967, 2, 184.

23 Short, D W, and Mackey, W A, Scottish Medical fournal, 1968, 13, 416

24 Slaney, G, et al, British Medical fournal, 1971, 2, 524.

25 Eastcott, H H G, Arterial Surgery, p 304. London, Pitman, 1973.

(Accepted 31 August 1977)

\title{
Further studies of sulphasalazine metabolism in the treatment of ulcerative colitis
}

\author{
G O COWAN, K M DAS, M A EASTWOOD
}

British Medical fournal, 1977, 2, 1057-1059

\section{Summary}

Sixty-four outpatients with ulcerative colitis receiving maintenance treatment with sulphasalazine were studied to relate disease activity to serum concentrations of sulphapyridine. Of 43 patients in remission, 32 had serum sulphapyridine levels over $20 \mu \mathrm{g} / \mathrm{ml}$. Ten of the 21 patients with active disease were for various reasons taking inadequate doses of sulphasalazine, as indicated

\footnotetext{
Wolfson Laboratories, Gastrointestinal Unit, Western General Hospital, Edinburgh EH4 2XU

G O COWAN, MB, MRCP, consultant physician. Lieutenant Colonel, RAMC

K M DAS, MD, PHD, research fellow (now assistant professor, Albert Einstein College of Medicine, Yeshiva University, New York)

M A EASTWOOD, MSC, FRCPED, consultant physician
}

by low serum sulphapyridine levels, and of the remaining 11 patients, who had serum levels over $20 \mu \mathrm{g} / \mathrm{ml}$, nine had faecal stasis proximal to active distal colitis and went into remission when treated with hydrophilic colloid or bran and an unchanged sulphasalazine dosage. This suggests that to be effective the metabolites of sulphasalazine must be delivered in the faeces to the lumen of the diseased distal segment of the colon.

High serum concentrations of sulphapyridine produce side effects; therefore slow acetylators of sulphapyridine need lower doses of sulphasalazine. Estimations of serum sulphapyridine concentrations, as well as identifying the patient's acetylation phenotype, can also be useful in assessing his compliance with treatment.

\section{Introduction}

The value of sulphasalazine (Salazopyrin) in treating ulcerative colitis is well-established. ${ }^{1-4}$ Sulphasalazine consists of sulphapyridine linked by an azo bond to 5-aminosalicylic acid. A small 